\title{
GCU
}

Glasgow Caledonian

University

University for the Common Good

\section{Satisfaction with democracy in Turkey: findings from a national survey}

Akboga, Sema; Sahin, Osman

Published in:

Politics

DOI:

$10.1177 / 0263395720943852$

Publication date:

2021

Document Version

Author accepted manuscript

Link to publication in ResearchOnline

Citation for published version (Harvard):

Akboga, S \& Sahin, O 2021, 'Satisfaction with democracy in Turkey: findings from a national survey', Politics, vol. 41, no. 2, pp. 207-223. https://doi.org/10.1177/0263395720943852

\section{General rights}

Copyright and moral rights for the publications made accessible in the public portal are retained by the authors and/or other copyright owners and it is a condition of accessing publications that users recognise and abide by the legal requirements associated with these rights.

Take down policy

If you believe that this document breaches copyright please view our takedown policy at https://edshare.gcu.ac.uk/id/eprint/5179 for details of how to contact us. 


\title{
Satisfaction with democracy in Turkey: Findings from a national survey
}

\begin{abstract}
A variety of factors affect citizens' satisfaction with democracy. Based on Turkey's political and economic context, as well as the existing literature, this study investigates the effect of four factors on people's satisfaction with democracy in Turkey: citizens' conceptualizations of democracy, being a political winner, citizens' perceptions of electoral integrity, and ethnic identity. Regression analysis of a nationally representative survey reveals that political losers and those with negative perceptions of electoral integrity are less satisfied with democracy in Turkey while people's conceptualizations of democracy and ethnic identity do not have an effect on satisfaction with democracy. We conclude that, in Turkey, political polarization and negative perceptions of electoral integrity trigger a decline in citizens' satisfaction with democracy, which requires the attention of policymakers.
\end{abstract}

Keywords: satisfaction with democracy; Turkey, electoral integrity; conceptualizations of democracy; political winner

\section{Introduction}

There has been a global recession of democracy over the last decade (Diamond, 2015;

Appadurai, 2017; Mounk, 2018), accompanied by increasing dissatisfaction with democracy in different parts of the world (Pew Research Center, 2019). In Turkey, people’s satisfaction with democracy has decreased since 2008 (Çarkoğlu and Aytaç, 2015; TSSEA 2018).

However, research demonstrated that citizens' positive evaluations of the political system are important for sustaining the stability of democratic regimes (Anderson and Guillory, 1997;

Anderson et al., 2005). This makes it important to understand the reasons for the decreasing levels of dissatisfaction with democracy. This research explores the factors conditioning people's level of satisfaction with democracy in Turkey and aims to understand whether certain groups are more dissatisfied with democracy than others.

There are different sources of people’s satisfaction with democracy (hereafter SWD). Among them are people’s conceptualizations of democracy, (Crow, 2010; Zhai, 2019), income and education (Anderson and LoTempio, 2002), political knowledge 
(Karp et al., 2003), exposure to media coverage (Banducci and Karp, 2003), the government's economic policies (Kim, 2009), the government's policies regarding corruption and the rule of law (Wagner et al., 2009), impartial and effective bureaucracy, the age of democracy in a country (Reher, 2015), election systems (Aarts and Thomassen, 2008), being a political winner (Blais and Gelineau, 2007), and electoral integrity (Norris, 2019). This research mainly focuses on four factors that might have an effect on people's SWD in Turkey: people's conceptualizations of democracy, being a political winner or loser, people’s perceptions of electoral integrity, and ethnic identity.

These four factors were selected because they are particularly relevant to Turkey’s social, political, and economic context. First, people in hybrid regimes tend to conceptualize democracy with reference to economic outcomes (Zagrebina, 2020). Democracy has been losing ground in Turkey since 2012 (EIU, 2020) and Turkey was defined as a hybrid regime in 2015 (EIU, 2015). While the Freedom House rating for Turkey was 3 in 2012, this score had declined to 5.5 in 2019 (1=most free, 7=least free) (Freedom House, 2019). However, between 2002 and 2015, ${ }^{1}$ the Turkish economy registered considerable growth under the Justice and Development Party (JDP) rule. From 2002 to 2015, GDP per capita (PPP) increased from \$9,215 to \$25,626 (World Bank, 2019). Accordingly, it is important to investigate whether people who define democracy in substantive terms are more satisfied with democracy in Turkey than are those who define democracy in procedural terms. Second, past research has revealed that being a political winner has a positive effect on SWD (Anderson and Guillory, 1997; Blais and Gelineau, 2007; Rich, 2015). Turkey is one of the most politically polarized countries in the world (Somer, 2019), where people's party identity shapes their attitudes towards institutions. For example, political winners (incumbent party 
voters) have more positive evaluations of state institutions than do political losers (opposition party voters) in Turkey (Sahin and Akboga, 2019). Political winners’ positive evaluations of state institutions in Turkey may be an extension of their support of the incumbent authorities rather than the result of their evaluations of the actual performance of these institutions. Political winners in Turkey are expected to be more satisfied with democracy, as they see the democratic performance of the country as another dimension of their support of the incumbent party. This research, therefore, includes being a political winner as another factor affecting SWD in Turkey. Third, people's perceptions of electoral integrity affect their SWD (Crow, 2010), especially in deeply divided societies (Norris, 2019) such as Turkey. In Turkey, which is marked by deep political and ethnic divisions, the share of people thinking that elections are not fair has increased in recent years (Çarkoğlu and Aytaç, 2015; TSSEA, 2018). This research considers perceptions of electoral integrity in Turkey as another factor affecting citizens' SWD. Fourth, ethnic identity has an effect on SWD (Gold, 2012; Ruiz-Rufino, 2013). Turkey is an ethnically divided society where the tensions between the state and Kurds have continued since the foundation of the Republic in 1923 (Yegen, 2009). Accordingly, this research considers ethnic identity as a factor affecting people’s SWD.

\section{Literature review and research hypotheses}

\section{Meanings of democracy and satisfaction with democracy}

The literature differentiates between procedural and substantive conceptions of democracy (Huang et al., 2013; Lu, 2013; Shin and Cho, 2010). While free and fair elections are central to procedural conceptions of democracy (Schumpeter, 2003; Przeworski, 2004), civil and political rights and freedoms are also considered important in this regard (Dahl, 1971; Norris, 2000; Zhai, 2019). People holding substantive conceptions democracy focus on the 
instrumental value of democracy (Zhai, 2019). They stress the policy outcomes of democracy, such as economic equality and socio-economic benefits (Zhai, 2019). In defining democracy, people prioritize one of these conceptions over the other (Bratton and Mattes, 2001; Baviskar and Malone, 2004; Shin and Cho, 2010; Dalton et al., 2007; Ariely, 2015).

While over $40 \%$ of people in established Western democracies define democracy with reference to procedural components (Dalton et al., 2007), a large number of people in other parts of the world equate democracy with substantive components (Baviskar and Malone, 2004). In some African countries, people include substantive components in their definitions of democracy (Bratton and Mattes, 2001). The majority of citizens in Algeria and Lebanon consider characteristics such as low economic inequality and basic necessities for all as more essential to democracy than procedural characteristics such as free elections and freedom of speech (Tessler et al., 2012). In Palestine and Jordan, the percentage of people stating that economic characteristics are more important to democracy than political characteristics is higher-58\% and 62\%, respectively (Tessler et al., 2012). In Latin America, substantive conceptualizations of democracy are very common (Canache, 2012). In Turkey, male Sunni Turks emphasize substantive dimensions whereas Alevis, Kurds, and female Sunni Turks prioritize procedural dimensions while defining democracy (Akboğa and Şahin, 2018).

The way in which people conceptualize democracy is important because it shapes what they expect from democracy in terms of its political and economic outcomes (Crow, 2010). These expectations, in turn, determine how people evaluate the performance of democracy in their societies (Zhai, 2019; Kornberg and Clarke, 1994). If there is a gap between what people expect from democracy and what is really happening in their country, they conclude that democracy is not working in the country (Crow, 2010). Indeed, previous research revealed that people’s conceptualizations of democracy have an impact on their SWD. In China, people who conceptualize democracy in terms of 
guardianship discourse, which emphasizes competent and virtuous leaders, are more satisfied with democracy than are those who conceptualize democracy in terms of procedures (Lu and Shi, 2015). In Slovenia, substantive conceptions of democracy are more important than procedural conceptions of democracy in determining people's SWD (Stebe, 2012). Canadians who emphasize that democracies provide people with a range of political and economic opportunities are more satisfied with democracy than are those whose definition stresses electoral processes and capitalist economics (Kornberg and Clarke, 1994). Research also showed that in African countries and in countries, such as Russia, Ukraine, Mexico, and Chile, those who have a procedural view of democracy express more SWD than do those who have a substantive view of democracy (Miller et al., 1997; Crow, 2010; Baviskar and Malone, 2004; Bratton and Mattes, 2001).

Congruency hypothesis suggests that people whose beliefs about democracy are more congruent with the prevailing political practices in the country make more favorable evaluations than those whose beliefs are at odds with prevailing practices (Kornberg and Clarke, 1994). For example, people in hybrid regimes tend to conceptualize democracy in substantive terms with reference to economic outcomes (Zagrebina, 2020) and when asked to assess the level of democracy, those who associate democracy with substantive dimensions actually evaluate the economic performance of their country (Zhai, 2019). These people therefore have higher levels of SWD especially when the economic growth is sustained in these countries (Zhai, 2019; Lu and Shi, 2015).

Based on congruency hypothesis, we suggest that despite the significant democratic backsliding after 2012, the economic growth between 2002 and 2015 might have contributed to positive evaluations of SWD for those who prioritize substantive dimensions of democracy in Turkey. After the 1980 military coup, Turkey has never been defined as a full democracy by the Freedom House. The EIU Democracy Index (2015) 
defines Turkey as a hybrid regime and notes an important decrease in Turkey’s overall democracy score after 2012. However, despite the ongoing economic crisis in Turkey since 2018, between 2002 and 2015, the Turkish economy registered important successes under the JDP rule. GDP per capita (PPP) increased from \$9,330 in 2002 to \$25,626 in 2015 while inflation decreased from 44.9\% in 2002 to 7.7\% in 2015 (World Bank, 2019). Therefore, in Turkey, those defining democracy in substantive terms might express more SWD than those holding a procedural definition of democracy as the former group's definition of democracy is more congruent with the economic growth in the country. This is because, when asked about their SWD in the country, those who define democracy in substantive terms might actually assess the economic performance of Turkey, which improved significantly between 2002 and 2015. Hence, our first hypothesis is as follows:

$\mathrm{H}_{1}$ : In Turkey, people who define democracy in substantive terms are more satisfied with democracy than are those who define democracy in procedural terms.

\section{Being a political winner and satisfaction with democracy}

Political winners, who vote for the incumbent party, are more likely to be satisfied with democracy than are political losers, who vote for the opposition parties. This is because citizens who vote for the winning party trust the incumbent party/the elected individual (Blais and Gelineau, 2007) or think that their interests are better served by that party/individual (Anderson and Guillory, 1997). However, for democratic consolidation in a country, what political losers feel about democracy is more important than what winners feel because losers are ‘the crucial veto players of democratic governance’ (Anderson et al., 2005:7). The survival of electoral democracy is, therefore, determined by its ability to secure the support of political losers (Nadeau and Blais, 1993). In other words, whether the political system can produce positive feelings on the part of losers is an important test of democracy (Henderson, 2008). 
Research showed the positive effect that being a political winner has on one's SWD (Blais and Gelineau, 2007; Anderson and Guillory, 1997; Banducci and Karp, 2003; Singh et al., 2012; Rich, 2015). Political losers in Europe, Canada, Germany, and the US are less satisfied with democracy than are political winners (Blais and Gelineau, 2007; Anderson and Guillory, 1997; Singh et al., 2012). In East Asian countries as well, political losers have lower evaluations of democracy than do political winners (Rich, 2015).

Turkey is a politically polarized country (Aydın-Düzgit and Balta, 2019; Aytaç et al., 2017). Polarization through political parties has increased considerably since the JDP came to power in 2002 (Yardımcı-Geyikçi, 2014), which resulted in significant differences between the winners and the losers in terms of their social and political attitudes. During the 2014 and 2018 presidential elections and the 2017 referendum, the votes were divided into two mutually disagreeing blocs (Somer, 2019). Research also revealed significant differences between the winners and losers in Turkey in terms of their views of state institutions (Örselli, 2016; Sahin and Akboga, 2019). The divisions between political winners and losers in Turkey increased to such an extent that in 2016, $74 \%$ of the people rejected the idea of their children playing with the children of someone who voted for another party (Erdogan, 2016). This level of polarization may also lead political winners to tolerate illiberal actions by the incumbent party (McCoy et al., 2018). We argue that being a winner or loser has an impact on SWD in Turkey because, due to the high levels of political polarization, people are likely to evaluate democracy from a partisan perspective. Hence, our second hypothesis is as follows:

$\mathrm{H}_{2}$ : In Turkey, political winners are more satisfied with democracy than are political losers. 


\section{Elections and satisfaction with democracy}

People regard free and fair elections as a central component of democracy (Ferrin and Kriesi, 2016) because free and fair elections are important for democratic accountability (Fukuyama, 2015) and, in representative democracies, voting is the only act by which citizens become directly involved in political processes. Accordingly, whether elections are conducted fairly has important consequences for citizens’ political behavior and attitudes (Norris, 2014; Alemika, 2007; Birch, 2012). In the case of electoral fraud, citizens' electoral choices are constrained, and citizens feel less able to shape policy outcomes and are less likely to perceive that the government is accountable and responsive (Fortin-Rittberger et al., 2017). Therefore, electoral fraud causes citizens to question the legitimacy of the government (Norris, 2019; Norris, 2014). If citizens think that elections are not fair, their distrust might spill over into other political institutions such as governments, parties, and parliaments, (Linde and Ekman, 2003) which, in turn, would have a negative effect on their SWD.

Research demonstrated a relationship between people’s perceptions of elections and their SWD. In Mexico, those who view past elections as clean are more satisfied with democracy (Crow, 2010). Kumlin and Esaiasson (2012) found that scandal elections, which are defined as elections in which a scandal involving politicians erupted or resurfaced in close proximity to voting time, have negative effects on SWD. FortinRittberger et al. (2017) demonstrated that high levels of electoral misconduct have a negative effect on citizens' SWD. Norris (2019) also revealed that people who perceive malpractice with respect to elections are less satisfied with how democracy works in their country. In Africa, those who consider elections as fair and free are more satisfied with democracy (Alemika, 2007). In Belarus, Russia, and Ukraine, people’s perceptions of electoral integrity are a significant predictor of SWD (McAllister and White, 2015). Along 
the same lines, Garnett (2019) found that public confidence in the fairness of the votecounting procedures positively affect citizens' SWD.

Although parliamentary elections have been held in modern Turkey since 1923, elections were neither free nor fair until 1950. Various amendments (supervision of elections by the judiciary and secret voting-open counting principle) that were introduced to the electoral law in 1950 made the electoral system relatively free and fair in Turkey. Despite persisting problems with the consolidation of democracy, Turkey took pride in its free and fair elections. However, in recent years, concerns about the integrity of elections have significantly increased. The most problematic dimensions of electoral integrity in Turkey have been the fairness of media coverage and manipulation of the electoral law (Norris et al., 2016). During the period before the 2014 local elections, Turkish public broadcaster TRT devoted 89\% of its time to the governing party (Akkoyunlu, 2017). Before the March 2014 local elections, the JDP doubled the number of metropolitan cities by implementing a new law_Law 6360, which changed the boundaries of electoral districts in its favor and caused the main opposition party to lose some important municipalities (Aygül, 2016).

As a result, in Turkey, the percentage of people who are concerned about the integrity of elections has increased over the last decade (Çarkoğlu and Aytaç, 2015). These concerns increased particularly after the general elections in November 2015 (Szymanski and Ufel, 2018). While 28\% of people indicated that elections would not be fair in 2007, this number rose to 43\% in 2015 (Çarkoğlu and Aytaç, 2015). Other research showed that $52 \%$ of people evaluated the campaign period before the 2017 referendum as unfair (IPSOS, 2017). Indeed, national and international organizations identified Turkey as a country with a low to very low degree of electoral integrity after the 2015 elections (OECD, 2017; Oy ve Otesi, 2017; Norris et al., 2016). In terms of electoral integrity, the 
2014 presidential elections were ranked $86^{\text {th }}$ out of 127 countries, whereas the 2015 general elections were ranked $101^{\text {st }}$ out of 139 countries (Norris et al, 2015; Norris et al., 2016). However, perceptions of the fairness of elections are important for citizens' SWD, especially in divided societies (Norris, 2019). Turkey is a politically polarized and divided country (Aydın-Düzgit and Balta, 2019; Somer, 2019) in which a considerable share of citizens has doubts about the integrity of elections. Hence, our third hypothesis is as follows:

$\mathrm{H}_{3}$ : In Turkey, people who perceive problems with the integrity of elections are less satisfied with democracy than are those who do not perceive problems with the integrity of elections.

\section{Ethnic identity and satisfaction with democracy}

There is limited research on the relationship between ethnic identity and SWD. Gold (2012) showed that citizens defining themselves in ethnic terms are less likely to be satisfied with democracy than citizens defining themselves in national terms. Similarly, Stockton (2006) found that in Taiwan, ethnic identity is one of the factors in explaining SWD. Research also demonstrated that ethnic minorities represented in the parliament are more satisfied with democracy than those minorities who are not represented in the parliament (Ruiz-Roffino, 2013).

In Turkey, Kurds are the second largest ethnic group after Turks. Kurds were denied their rights and were subjected to assimilationist policies by the Turkish state (Yegen, 2009). The state imposed a state of emergency in the largely Kurdish southeast between 1987 and 2002, which exacted a heavy toll on the Kurdish minority (Çelik, 2005). Between 1980 and 2001, at least 1,353 people disappeared by forces connected to the state and thousands of murders in the region stayed unsolved (Goral et al., 2013). In the same period, the state forcibly displaced around 400,000 Kurds (Çelik, 2005). These policies of the state caused Kurds to trust state institutions less than Turks in Turkey (Sahin and 
Akboga, 2019). We suggest that the state policies and Kurds’ distrust of the state institutions may have negative spillover effects on Kurds' SWD in Turkey. We therefore hypothesize that:

$\mathrm{H}_{4}$ : In Turkey, Kurds are less satisfied with democracy than are Turks.

\section{Methods}

\section{Data}

This study used the data from a face-to-face national survey, which was conducted between March 2015 and May 2015 with 1,804 people who were at least 18 years old. The survey measured people's perceptions of democracy and the rule of law in Turkey. The participants were randomly selected across 12 regions of Turkey in accordance with the Turkish Statistical Institute’s (TUIK) NUTS-12 system. We determined the number of participants in each region in proportion to that region's population. Appendix 1 shows the number of survey participants from each sub-region along with the names of cities in parentheses.

TUIK provided the researchers with 180 randomly sampled geographical areas in Turkey. Interviewers were asked to complete 10 surveys from each sampling unit and started with the beginning address that had been randomly chosen by TUIK. If the person whose name started with the letter closest to ' $A$ ' was not present, the interviewer visited the same address for a second time. If the person was not at home during the second visit, the interviewer visited the next address. After completing the first survey, the interviewer visited every three addresses to the right for the next survey until 10 interviews had been completed in each sampling unit.

The survey questions were written based on two sources: (1) interviews conducted with 60 people in five cities (Istanbul, Kayseri, Adana, Trabzon, and Diyarbakir) in Turkey and (2) surveys such as the World Values Survey and World Justice Project 
Survey. During the interviews, participants were asked about their perceptions about democracy and elections in Turkey as well as about their conceptualizations of democracy. Some questions in the survey were formulated based on repeated patterns detected in these interviews. The questions were finalized after the analysis of the pilot survey that was conducted with 100 people in five cities.

\section{Dependent variable}

As a means of measuring people’s SWD in Turkey, the participants were asked, 'How well do you think democracy works in Turkey?' and then they selected a number ranging between 1 (very bad) and 5 (very good/well).

\section{Independent variables}

Substantive democracy: People’s understanding of democracy was measured by asking the participants to choose the most important feature of democracy from a six-category scale: 'opportunity to change the government through elections', 'freedom to criticize the government', 'reducing the gap between rich and poor', 'providing the basic necessities of citizens (food, shelter, and clothes)', 'citizens have equal political rights', and 'eliminating financial and administrative corruption'. The exact wording of the question was as follows: 'There are different views on the most important features of democracy among people. If you had to choose, which of the following feature of democracy would be the most important for you?' We created a dummy variable by recoding this variable. Those who prioritized one of the substantive aspects of democracy ('reducing the gap between rich and poor', 'providing the basic necessities of citizens (food, shelter, and clothes)', and 'eliminating financial and administrative corruption') were recoded as ' 1 ', whereas those who prioritized one of the procedural aspects of democracy ('opportunity to change the government through elections', 'freedom to criticize the government', and 
'citizens have equal political rights') were recoded as ' 0 '. We named this variable

\section{Substantive democracy.}

Political winner: Being a political winner was measured by asking the participants the following question: 'If there were general elections next Sunday, which political party would you vote for?' Those expressing their intention, or indicating their inclination, to vote for the incumbent JDP were coded as ' 1 '. Those expressing their intention, or indicating their inclination, to vote for opposition parties were coded as ' 0 '. We named this variable Political winner.

Electoral fraud: People’s perceptions of electoral fraud were measured with a question asking for their opinions about the local elections held on October 30, 2014, which was the most recent election before the data collection. In Turkey, local elections are almost as important as general elections, as they indicate the level of support for the incumbent and opposition parties. The participants were asked, 'How free and fair were the municipal elections held on 30 March 2014?’ This question had a three-category scale: 'it was not free and fair', 'despite some problems it was free and fair', and 'it was completely free and fair'. We created a dummy variable by recoding this question. 'It was not free and fair' was recoded as ' 1 '. 'Despite some problems it was free and fair' and 'it was completely free and fair' were recoded as '0'. We named this new variable Electoral fraud.

Ethnic identity: This variable, which we named Ethnic identity, is a dummy variable using the following question: 'Which ethnic group do you belong to?' Those who chose the option 'Kurd' were coded as ' 1 ', while 'Turk' was coded as ' 0 '. Since this variable aimed to measure the differences between Kurds and Turks, those who indicated that their ethnicity was neither Kurdish nor Turkish were coded as 'system missing'. 


\section{Control variables}

Past research showed that SWD is conditioned by individuals' social and cultural characteristics (Bratton and Mattes, 2001). The following control variables were included in the analysis: Age (between 18 and 91), Female (female =1; male = 0), Education (1 = no schooling; 2 = 5-year degree; 3 = 8-year degree; 4 = high school degree; 5 = higher education degree), and Household expenditure (1 = under 500 Turkish Lira (TL) per month; 2 = 500-1000 TL per month; 3 = 1001-1500 TL per month; 4 = 1501-2500 TL per month; 5 = 2501-3500 TL per month; 6 = 3501-5000 Turkish Lira per month; 7 = 5001-7000 TL per month; 8 = over 7000 TL per month).

Another control variable named Corruption was also included in the analysis. Whether corruption is common or not in a country affects people's SWD (Wagner et al., 2009). This variable was constructed by using the participants’ answers to the following statement: 'In Turkey, corruption and bribery are not common'. The participants were asked to choose a number between ' 1 ' (completely disagree) and '5' (completely agree). We reverse coded this variable so that higher scores mean higher perceptions of corruption.

The most problematic dimension of electoral integrity in Turkey has been the fairness of media coverage (Norris et al., 2016). The majority of television channels, including the state-owned TRT, devoted more time to the representatives of the incumbent party for their election propaganda (Akkoyunlu, 2017). Accordingly, another control variable named Media freedom, which aims to measure people's perception of media freedom in Turkey, was included in the analysis. This measure used the responses to the following statement: 'In Turkey, there is no government intervention to the media'. The participants were asked to choose a number between ' 1 ' (completely disagree) and ‘5’ (completely agree). 
The last control variable is an interaction term. This variable was created using a procedure in which Substantive democracy was multiplied by Electoral fraud. The resulting variable measures whether the effect of people’s perceptions of electoral fraud on their SWD is moderated by their conceptualizations of democracy. Perceptions of electoral fraud might have less impact on SWD for those who conceptualize democracy in substantive terms as they attribute less importance to the procedures of democracy.

\section{Results}

\section{Descriptive statistics}

Table 1 summarizes the descriptive statistics for all variables in the analysis. The mean score for SWD is $2.73 / 5$. The mean score for corruption $(3.92 / 5)$ indicates that perceptions of corruption are high in Turkey. The mean score for media freedom is 2.63/5. The average education is 3.25/5, which puts the education level in our sample somewhere between an eight-year degree and a high school degree. The mean score for household expenditure is 3.31, putting the average household expenditure somewhere above 1500 TL and below 2500 TL in 2015 prices.

Table 1. Descriptive statistics for variables $(\mathrm{N}=1804)$

\begin{tabular}{|l|c|c|c|c|}
\hline & Minimum & Maximum & Mean & Standard deviation \\
\hline $\begin{array}{l}\text { Satisfaction with } \\
\text { democracy }\end{array}$ & 1 & 5 & 2.73 & 1.17 \\
\hline Age & 17 & 91 & 38.76 & 13.67 \\
\hline Sex & 0 & 1 & .49 & .50 \\
\hline Education & 1 & 5 & 3.25 & 1.23 \\
\hline Household expenditure & 1 & 8 & 3.31 & 1.22 \\
\hline Kurdish identity & 0 & 1 & .19 & .39 \\
\hline Substantive democracy & 0 & 1 & .39 & .49 \\
\hline Political winner & 0 & 1 & .38 & .48 \\
\hline Electoral fraud & 0 & 1 & .38 & .48 \\
\hline Corruption & 1 & 5 & 3.92 & 1.17 \\
\hline Media freedom & 1 & 5 & 2.63 & 1.267 \\
\hline $\begin{array}{l}\text { Substantive democracy* } \\
\text { electoral fraud }\end{array}$ & 0 & 1 & .16 & .367 \\
\hline
\end{tabular}


Table 2 shows the means of categorical variables for the dependent variable. The average score of SWD for Turks (2.82) is higher than it is for Kurds (2.39). The mean score of SWD for those prioritizing substantive features of democracy is 2.94 , while it is 2.58 for those prioritizing procedural features of democracy. Political winners have an average score of 3.59 on SWD while this score is 2.20 for political losers. For those thinking that elections are neither free nor fair, the average score of SWD is 2.10 while it is 3.10 for people who think that elections in Turkey are free and fair.

Table 2. Mean scores of categorical variables for dependent variable

\begin{tabular}{|l|c|c|c|}
\hline & Mean & N & Std. Deviation \\
\hline Male & 2.69 & 906 & 1.174 \\
\hline Female & 2.76 & 887 & 1.168 \\
\hline Turk & 2.82 & 1399 & 1.167 \\
\hline Kurd & 2.39 & 326 & 1.106 \\
\hline Substantive & 2.94 & 701 & 1.164 \\
\hline Procedural & 2.58 & 1086 & 1.154 \\
\hline Political loser & 2.20 & 856 & 1.043 \\
\hline Political winner & 3.59 & 517 & .914 \\
\hline $\begin{array}{l}\text { Electoral fraud (free and } \\
\text { fair) }\end{array}$ & 3.10 & 1054 & 1.071 \\
\hline $\begin{array}{l}\text { Electoral fraud (not free } \\
\text { and fair) }\end{array}$ & 2.10 & 633 & 1.050 \\
\hline $\begin{array}{l}\text { Substantive*electoral } \\
\text { fraud (reference) }\end{array}$ & 2.29 & 174 & 1.118 \\
\hline
\end{tabular}

Dependent variable: Satisfaction with democracy

\section{Multivariate regression analysis}

Table 3 below summarizes the results of the multivariate regression analysis. Model 1, which is our baseline model, includes main independent variables as well as demographic variables. In Model 1, Age has a negative and significant effect in the model $(\mathrm{p}<0.05)$. In Turkey, older people are less satisfied with democracy than are younger people.

Substantive democracy $(\mathrm{p}<0.05)$ and Political winner $(\mathrm{p}<0.001)$ have a significant and 
positive effect on the dependent variable. Electoral fraud $(\mathrm{p}<0.001)$ and Ethnic identity $(\mathrm{p}<0.05)$ have a negative and significant effect on the dependent variable $(\mathrm{p}<0.001)$.

Model 2 introduces the following control variables to the analysis: Corruption, Media freedom, Substantive democracy*Electoral fraud. The interaction term did not have any significant effect in Model 2. Corruption has a significant and negative effect (p $<0.001$ ) while Media freedom has a significant and positive effect in the model. Those who think that bribery and corruption are common in Turkey as well as those who think that the government intervenes in media are less satisfied with democracy in Turkey. After introducing these variables, Substantive democracy and Ethnic identity lose their significant effect in Model 2. This finding does not provide support for the first and fourth hypotheses. Accordingly, ethnic identity and people’s conceptualizations of democracy do not have a significant effect on SWD in Turkey. In Model 2, Political winner $(\mathrm{p}<0.001)$ and Electoral fraud $(\mathrm{p}<0.001)$ variables maintain their significant effect. These findings provide support for the second and third hypotheses. In Turkey, political winners are more satisfied with democracy than are political losers and those who think that elections are not free and fair are less satisfied with democracy. 
Table 3. Multivariate regression analysis

\begin{tabular}{|c|c|c|c|c|}
\hline \multirow{2}{*}{ Model } & \multicolumn{2}{|c|}{ Model 1} & \multicolumn{2}{|c|}{ Model $2^{2}$} \\
\hline & $\begin{array}{l}\text { Unstandardized } \\
\text { Coefficients }\end{array}$ & $\begin{array}{l}\text { Standardized } \\
\text { Coefficients }\end{array}$ & $\begin{array}{c}\text { Unstandardized } \\
\text { Coefficients }\end{array}$ & $\begin{array}{l}\text { Standardized } \\
\text { Coefficients }\end{array}$ \\
\hline (Constant) & $2.895(.179)$ & & $2.054^{* * *}(.186)$ & \\
\hline Age & $-.005^{*}(.002)$ & -0.056 & $-.005^{*}(.002)$ & -.058 \\
\hline Gender & $-.093(.058)$ & -0.039 & $-.084(.056)$ & -.035 \\
\hline Education & $.001(.027)$ & 0.001 & $.006(.026)$ & .006 \\
\hline Household expenditure & $-.033(.025)$ & -0.033 & $-.028(.024)$ & -.028 \\
\hline Substantive democracy & $.129^{*}(.061)$ & 0.052 & $.083(.071)$ & .033 \\
\hline Political winner & $1.044^{* * *}(.069)$ & 0.422 & $.670^{* * *}(.074)$ & .270 \\
\hline Electoral fraud & $-.536^{* * *}(.066)$ & -0.22 & $-.431^{* * *}(.074)$ & -.176 \\
\hline Ethnic identity & $-.249^{*}(.079)$ & -0.081 & $-.041(.079)$ & -.013 \\
\hline Corruption & & & $-.188^{* * *}(.028)$ & .189 \\
\hline Media freedom & & & $.182^{* * *}(.026)$ & .197 \\
\hline Substantive democracy*Electoral fraud & & & $.084(.121)$ & .021 \\
\hline Adjusted $\mathrm{R}^{2}$ & \multicolumn{2}{|c|}{.344} & \multicolumn{2}{|c|}{.414} \\
\hline D.f. & \multicolumn{2}{|c|}{1163} & \multicolumn{2}{|c|}{1142} \\
\hline
\end{tabular}

Dependent variable: Satisfaction with democracy

a. Entries are coefficients of multivariate linear regressions with standard errors in parentheses. ${ }^{*} \mathrm{p}<0.05 ;{ }^{* * *} \mathrm{p}<0.001$

\section{Discussion and conclusion}

Based on the social, economic, and political context in Turkey, this research investigated four variables to understand why citizens in Turkey have been increasingly less satisfied with democracy. Major findings are as follows: In Turkey, political winners are more satisfied with democracy than are political losers. This finding supports previous research on the relationship between being a political winner and SWD (Anderson and Guillory, 1997; Blais and Gelineau, 2007). Standardized coefficients of the regression analysis indicated that being a political winner has the largest effect on SWD. That is, party identity is more important than other variables in determining citizens' SWD in Turkey. This suggests that in Turkey political winners' high SWD is likely to be an extension of 
their support for the incumbent party rather than being the result of their evaluations of the performance of democratic institutions. This finding also supports the previous research indicating high levels of political polarization based on party identity in Turkey (Aydın-Düzgit and Balta, 2019; Somer, 2019). However, it is worrisome because political losers' SWD is important for a democratic regime (Nadeau and Blais, 1993). High levels of polarization may also lead the political winners to tolerate illiberal actions of the incumbent party (McCoy et al., 2018), with the potential to further the decline in Turkish democracy.

In Turkey, the lower one's perception of electoral integrity, the less likely one is to be satisfied with democracy. This finding contributes to the emerging literature on the relationship between perceptions of electoral integrity and SWD (Fortin-Rittberger et al., 2017). As Norris (2019) argued, especially in divided societies, perceptions of electoral integrity are even more important for citizens' SWD. The increasing concern about the fairness of elections in Turkey, a country marked by ethnic and political divisions, decreases the level of SWD.

Despite the problems regarding the consolidation of democracy in Turkey, the majority (60.6\%) emphasized procedural characteristics in their conceptualizations of democracy. This finding contradicts with previous research indicating that people in hybrid regimes are more likely to conceptualize democracy with reference to economic outcomes (Zagrebina, 2020). Furthermore, how people conceptualize democracy did not have an impact on their SWD in Turkey. We conclude that, in Turkey, the economic growth between 2002 and 2015 did not produce a significant increase in SWD among citizens who primarily associate democracy with economic benefits. This result indicates that the findings of previous research on SWD in authoritarian countries, where people who conceptualize democracy in substantive terms are more satisfied with democracy 
(Zhai, 2019), may not apply to countries such as Turkey, which was considered as a hybrid regime in 2015 (EIU, 2015).

The finding that people's conceptualizations of democracy lost its significance after introducing perceptions of corruption and media freedom to the model deserves attention. Further investigation showed that people who prioritize substantive dimensions of democracy (mean=2.87/5) are more likely than those who prioritize procedural dimensions of democracy (mean=2.48/5) to think that there is no government intervention to the media. When people were asked to express their opinions about a concrete dimension of procedural democracy in Turkey, compared to being asked about democracy as an abstract concept, they might have expressed their opinions stronger, which in turn reduced the effect of their abstract conceptualizations of democracy on SWD. We therefore suggest that future research on the determinants of SWD to include more concrete measures that have relevance to political and social context of the country under consideration.

In contrast to previous research on ethnic identity and SWD (Gold, 2012), our analysis did not find any significant effect of ethnic identity on SWD in Turkey. Similar to people's conceptualizations of democracy, ethnic identity lost its significance after perceptions of corruption and media freedom were introduced to the regression model. Further investigation revealed that perceptions of corruption are higher for Kurds $($ mean $=4.45 / 5)$ than it is for Turks (mean=3.77/5). Similarly, Kurds (mean=1.89/5) are less likely than Turks (mean=2.79/5) to think that there is no state intervention to the media in Turkey. Unfair treatment of Kurds by the state caused them to have lower perceptions of procedural fairness of the state institutions than Turks (Sahin and Akboga 2019). This in turn might have contributed to more negative perceptions of corruption amongst Kurds. Furthermore, throughout the Republican history, pro-Kurdish media 
outlets were regularly targeted, and Kurdish journalists were jailed by the state.

Accordingly, compared to Turks, Kurds are more likely to think that the media in Turkey is not free. We therefore conclude that in Turkey, Kurds’ perceptions about the media freedom and the quality of institutions are more powerful predictors of SWD than their ethnic identity.

Despite these important findings, three potential limitations of the study should be mentioned. First, there are problems in conducting face-to-face surveys in countries that are not considered as fully democratic. Turkey was assessed as a hybrid regime in 2015 (EIU, 2015), which might have caused some participants to express more favorable opinions than they really have about the situation of democracy. Second, this study fails to include some important variables such as citizens' political knowledge as the survey did not have questions pertaining to these issues. Third, there might be endogeneity problems caused by reverse causation. That is, SWD might have an effect on some independent variables in the regression model such as perceptions of electoral fraud.

The global recession of democracy over the last decade (Diamond, 2015; Appadurai, 2017; Mounk, 2018) should encourage more studies on democracy, as democratic recession is also accompanied by increasing citizen dissatisfaction with democracy (Pew Research Center, 2019). The share of people open to authoritarian alternatives to democracy is on the rise, even in advanced democracies (Pew Research Center, 2019). It is therefore important to understand the factors causing people to be dissatisfied with democracy. The current research has contributed to the literature on democracy, as it is one of the very few empirical studies on SWD in Turkey. This research bears important lessons for policymakers by revealing who is more dissatisfied with democracy in Turkey. By demonstrating the effects of political polarization, perceptions of electoral integrity, corruption, and media freedom on citizens' SWD, this 
research indicates that policymakers in Turkey should particularly focus on these

problems to improve regime’s standing with the citizens.

\footnotetext{
${ }^{1}$ This study does not take into consideration economic indicators or developments in Turkey after 2015 as the data was collected in 2015. Accordingly, the ongoing economic crisis in Turkey does not pertain to the main argument in this study.

${ }^{2}$ When Substantive democracy and Ethnic identity lost their significance after the introduction of control variables in Model 2, we controlled this model for multicollienarity. Analysis showed that VIF scores, a measure of multicollienarity, are below 2 indicating that Model 2 does not suffer from multicollienarity.
} 


\section{References}

Aarts K and Thomassen J (2008) Satisfaction with democracy: Do institutions matter? Electoral Studies 27(1): 5-18.

Akboğa S and Şahin O (2018) Perceptions of democracy in Turkey: Gender, ethnic, and religious dynamics. Journal of Economy, Culture and Society 57(1): 1-28.

Akkoyunlu K (2017) Electoral integrity in Turkey: From tutelary democracy to competitive authoritarianism. In: Başer B and Öztürk AE (eds) Authoritarian Politics in Turkey: Elections, Resistance, and the AKP. London: I. B. Tauris, pp. 47-63.

Alemika E (2007) Quality of elections, satisfaction with democracy, and political trust in Africa. Afrobarometer Working Paper 8.

Anderson CJ and LoTempio AJ (2002) Winning, losing and political trust in America. British Journal of Political Science 32(2): 335-351.

Anderson CJ and Guillory CA (1997) Political institutions and satisfaction with democracy: A cross-national analysis of consensus and majoritarian systems. The American Political Science Review 91(1): 66-81.

Anderson CJ, Blais A, Bowler S, Donovan T and Listhaug O (2005) Losers' Consent: Elections and Democratic Legitimacy. Oxford: Oxford University Press.

Appadurai A (2017) Democracy fatigue. In: Geiselberger H (ed), The Great Regression. Cambridge, MA: Polity Press, 1-12.

Ariely G (2015) Democracy-assessment in cross-national surveys: A critical examination of how people evaluate their regime. Social Indicators Research 121(3): 621-635.

Aydın-Düzgit S and Balta E (2019) When elites polarize over polarization: Framing the polarization debate in Turkey. New Perspectives on Turkey 59(1): 153-176.

Aygül C (2016). Electoral manipulation in March 30, 2014 Turkish local elections. Turkish Studies 17(1): 181-201.

Aytaç ES, Çarkoğlu A and Yıldırım K (2017) Taking sides: determinants of support for a presidential system in Turkey. South European Society and Politics 22(1): 1-20.

Banducci SA and Karp JA (2003) How elections change the way citizens view the political system: Campaigns, media effects and electoral outcomes in comparative perspective. British Journal of Political Science 33(3): 443-67.

Baviskar S and Malone MFT (2004) What democracy means to citizens- and why it matters. Revista Europea de Estudios Latinoamericanos y del Caribe 76: 3-23.

Birch S (2012) Electoral Malpractice. Oxford: Oxford University Press.

Blais A and Gélineau F (2007) Winning, losing and satisfaction with democracy. Political 
Studies 55(2): 425-441.

Bratton M and Mattes R (2001) Support for democracy in Africa: Intrinsic or instrumental? British Journal of Political Science 31(3): 447-474.

Canache D (2012) Citizens’ conceptualizations of democracy: Structural complexity, substantive content, and political significance. Comparative Political Studies 45(9): 1132-1158.

Çelik AB (2005) Transnationalization of human rights norms and its impact on internally displaced Kurds. Human Rights Quarterly, 27(3): 969-997.

Crow D (2010) The party's over: Citizen conceptions of democracy and political dissatisfaction in Mexico. Comparative Politics 43(1): 41-61.

Çarkoğlu A and Aytaç E (2015) Haziran 2015 Seçimlerine Giderken Kamuoyu Dinamikleri [Public Dynamics Before the June 2015 Elections]. Available at: http://home.ku.edu.tr/ saytac/uploads/4/4/6/3/44632775/Haziran2015_sunum.pdf (accessed November 2019).

Dahl RA (1971) Polyarchy: Participation and opposition. New Haven and London: Yale University Press.

Dalton RJ, Jou W and Shin DC (2007) Understanding democracy: Data from unlikely places. Journal of Democracy 18(4): 142-156.

Diamond L (2015) Facing up to the democratic recession. Journal of Democracy 26(1): 141155.

EIU (2015) Democracy index 2015. Available at: http://www.eiu.com/Handlers/WhitepaperHandler.ashx?fi=EIU-Democracy-Index2015.pdf\&mode=wp\&campaignid=DemocracyIndex2015 (accessed April 2020)

EIU (2020) Democracy index 2019. Available at:

https://www.eiu.com/n/global-democracy-in-retreat/ (accessed January 2020)

Erdogan E (2016) Turkey: Divided we stand. Washington, DC: German Marshall Fund.

Ferrin M and Kriesi H (2016) Introduction. In: Ferrin M and Kriesi H (eds) How Europeans View and Evaluate Democracy. Oxford: Oxford University Press, 1-21.

Fortin-Rittberger J, Harfst P and Dingler SC (2017) The costs of electoral fraud: Establishing the link between electoral integrity, winning an election, and satisfaction with democracy. Journal of Elections, Public Opinion and Parties 27(3): 350-368.

Freedom House (2019) Democracy in Retreat: Freedom in the World 2019. Available at: https://freedomhouse.org/report/freedom-world/freedom-world-2019 (accessed December 2019). 
Fukuyama F (2015) Why is democracy performing so poorly? Journal of Democracy 26(1): $11-20$.

Garnett HA (2019) On the front lines of democracy: Perceptions of electoral officials and democratic elections. Democratization 26(8): 1399-1418.

Gold V (2012) Partitioning ethnic groups and their members: Explaining variations on satisfaction with democracy in Africa. PEPS 18(3): 1-13.

Göral Ö. S, Işı A and Kaya Ö (2013) The unspoken truth: Enforced disappearances. Istanbul: Truth Justice Memory Center.

Henderson A (2008) Satisfaction with democracy: The impact of winning and losing in Westminster systems. Journal of Elections, Public Opinion and Parties 18(1): 3-26.

Huang M, Chu Y and Chang Y (2013) Popular understanding of democracy and regime legitimacy. Taiwan Journal of Democracy 9(1): 147-71.

IPSOS (2017) Anayasa değişikliği referandumu sandık sonrası araştırması [Research after the referendum on constitutional amendments]. Available at:

https://www.ipsos.com/tr-tr/anayasa-degisikligi-referandumu-sandik-sonrasiarastirmasi?language_contententity=tr-tr (accessed October 2019).

Istanbul Bilgi University Center for Migration Research (2018) Türkiye'de kutuplaşmanın boyutları araştırması 2018 [Dimensions of polarization in Turkey 2018]. Available at: https://goc.bilgi.edu.tr/media/uploads/2018/02/05/bilgi-goc-merkezi-kutuplasmaninboyutlari-2017-sunum.pdf (accessed October 2019).

Karp JA, Banducci SA and Bowler S (2003) To know it is to love it?: Satisfaction with democracy in the European Union. Comparative Political Studies 22(3): 1-22.

Kim M (2009) Cross-national analyses of satisfaction with democracy and ideological congruence. Journal of Elections, Public Opinion and Parties 19(1): 49-72.

Kornberg A and Clarke HD (1994) Beliefs about democracy and satisfaction with democratic government: The Canadian case. Political Research Quarterly 47(3): 537-563.

Kumlin S and Esaiasson P (2012) Scandal fatigue? Scandal elections and satisfaction with democracy in Western Europe, 1977-2007. British Journal of Political Science 42(2): 263-282.

Linde J and Ekman J (2003) Satisfaction with democracy: A note on a frequently used indicator in comparative politics. European Journal of Political Research 42(3): 391408.

Lu J (2013) Democratic conceptions in East Asian societies: A contextualized analysis. Taiwan Journal of Democracy 9(1): 117-145.

Lu J and Shi T (2015) The battle of ideas and discourses before democratic transition: 
Different democratic conceptions in authoritarian China. International Political Science Review 36(1): 20-41.

McAllister I and White S (2015) Electoral integrity and support for democracy in Belarus, Russia, and Ukraine. Journal of Elections, Public Opinion \& Parties 25(1): 78-96.

McCoy J, Rahman T and Somer M (2018) Polarization and the global crisis of democracy: Common patterns, dynamics, and pernicious consequences for democratic polities. American Behavioral Scientist 62(1): 16-42.

Miller AH, Hesli VL and Reisinger WM (1997) Conceptions of democracy among mass and elite in post-Soviet societies. British Journal of Political Science 27(2): 157-190.

Mounk Y (2018) The People vs. Democracy. Cambridge: Harvard University Press.

Nadeau R and Blais A (1993) Accepting the election outcome: The effect of participation on losers’ consent. British Journal of Political Science 23(4): 553-63.

Norris P (2000) Democratic divide? The impact of the internet on parliaments worldwide. Paper presented at the American Political Science Association Annual Meeting, Washington, August 31- September 1, 2000.

Norris P (2014) Why Electoral Integrity Matters. Cambridge: Cambridge University Press.

Norris P, Coma FM and Gromping M (2015) The world's flawed and failed contests. The year in elections, 2014. The Electoral Integrity Project. Available at: https://research.hks.harvard.edu/publications (accessed October 2019)

Norris P, Coma FM, Nai A and Gromping M (2016) The Year in Elections 2015. Sydney: University of Sydney.

Norris P (2019) Do perceptions of electoral malpractice undermine democratic satisfaction? The US in comparative perspective. International Political Science Review 40(1): 522.

OECD (2017) Republic of Turkey constitutional referendum. OSCE/ODIHR Limited Referendum Observation Mission Final Report. Avaliable at: http://www.osce.org/odihr/elections/turkey/324816 (accessed September 2019)

Örselli E (2016) Türkiye’de Yarglya Güven [Trust in Judiciary in Turkey]. Konya: Çizgi Kitabevi.

Oy ve Otesi (2017) Referendum değerlendirmesi [An evaluation of the referendum]. http://oyveotesi.org/referandumdegerlendirmesi/

Pew Research Center (April, 2019) Many across the globe are dissatisfied with how democracy is working.

Przeworski A (2004) Democracy and economic development. In: Mansfield ED and Sisson R 
(eds) Political Science and the Public Interest. Columbus: Ohio State University Press, pp. 300-325.

Reher S (2015) Explaining cross-national variation in the relationship between priority congruence and satisfaction with democracy. European Journal of Political Research 54(1): 160-181.

Rich TS (2015) Losers' consent or non-voter consent? satisfaction with democracy in East Asia. Asian Journal of Political Science 23(3): 243-259.

Ruiz-Rufino R (2013) Satisfaction with democracy in multi-ethnic countries: The effect of representative political institutions on ethnic minorities. Political Studies 61(1): 101118.

Sahin O and Akboga S (2019) Ethnic identity and perceptions of the police in Turkey: The case of Kurds and Turks. Policing and Society 29(8): 985-1000.

Schumpeter JA (2003) Capitalism, Socialism and Democracy. London and New York: Routledge.

Shin DC and Cho Y (2010) How East Asians understand democracy from a comparative perspective. ASIEN 116: 21-40.

Singh S, Karakoç E and Blais A (2012) Differentiating winners: How elections affect satisfaction with democracy. Electoral Studies 31(1): 201-211.

Somer M (2019) Turkey: The slippery slope from reformist to revolutionary polarization and democratic breakdown. ANNALS, AAPSS 681(1): 42-61.

Stebe J (2012) Support for democracy and meanings for democracy: Equality and freedom. Teorija in Praksa 49(3): 516-543.

Stockton H (2006). Partisanship, ethnic identification, and citizen attitudes toward regime and government on Taiwan. Journal of Contemporary China 15(49): 705-721.

Szymanski A and Ufel W (2018) Beyond vote rigging: Common patterns in dedemocratizing regimes. Polish Political Science Yearbook 47(4): 593-617.

Tessler M, Jamal A and Robbins M (2012) New findings on Arabs and democracy. Journal of Democracy 23(4): 89-103.

TSSEA (Türkiye Sosyal-Siyasal Eğilimler Araştırması) (2018) Kadir Has Üniversitesi Türkiye Çalışmaları Merkezi. Available at: http://ctrs.khas.edu.tr/sources/TSSEA2018-TR.pdf (accessed September 2019)

Wagner A, Schneider F and Halla M (2009) The quality of institutions and satisfaction with democracy in western Europe-A panel analysis. European Journal of Political Economy 25(1): 30-41.

World Bank (2019) Turkey. Available at: 
https://data.worldbank.org/indicator/NY.GDP.PCAP.PP.CD?locations=TR (accessed November 2019)

Yardımc1-Geyikçi Ş (2014) Gezi-Park protests in Turkey: A party view politics. The Political Quarterly 85(4): 445-453.

Zagrebina A (2020) Concepts of democracy in democratic and nondemocratic countries. International Political Science Review 41(2): 174-191.

Zhai Y (2019) Popular conceptions of democracy and democratic satisfaction in China. International Political Science Review 40(2): 246-262.

Yegen M (2009) Prospective Turks or pseudo citizens: Kurds in Turkey. Middle East Journal, 63(4): 597-615. 
Appendix 1. Distribution of sample across the regions as provided by TUIK

\begin{tabular}{|l|l|c|c|c|c|}
\hline & & $\begin{array}{c}\text { Total } \\
\text { number of } \\
\text { survey } \\
\text { participants }\end{array}$ & $\begin{array}{c}\text { Number of } \\
\text { survey } \\
\text { participants } \\
\text { in urban } \\
\text { centers }\end{array}$ & $\begin{array}{c}\text { Number of } \\
\text { survey } \\
\text { participants } \\
\text { in semi- } \\
\text { rural } \\
\text { centers }\end{array}$ & $\begin{array}{c}\text { Number of } \\
\text { survey } \\
\text { participants } \\
\text { in rural } \\
\text { centers }\end{array}$ \\
\hline TR1 & Istanbul & 331 & 321 & 10 & 0 \\
\hline TR2 & West Marmara (Balikesir) & 74 & 66 & 0 & 8 \\
\hline TR3 & Aegean (Izmir) & 231 & 210 & 21 & 0 \\
\hline TR4 & East Marmara (Bursa) & 176 & 128 & 48 & 0 \\
\hline TR5 & West Anatolia (Ankara) & 176 & 176 & 0 & 0 \\
\hline TR6 & Mediterranean (Adana) & 231 & 184 & 41 & 6 \\
\hline TR7 & Central Anatolia (Kayseri) & 86 & 60 & 22 & 4 \\
\hline TR8 & West Black Sea (Samsun) & 108 & 69 & 9 & 30 \\
\hline TR9 & East Black Sea (Trabzon) & 56 & 43 & 1 & 12 \\
\hline TRA & Northeast Anatolia (Erzurum) & 55 & 29 & 12 & 14 \\
\hline TRB & Mideast Anatolia (Malatya) & 88 & 61 & 2 & 25 \\
\hline TRC & Southeast Anatolia (Diyarbakir) & 192 & 142 & 34 & 16 \\
\hline & Total & 1804 & 1489 & 200 & 115 \\
\hline
\end{tabular}

